\title{
Analysis of Indigenous Communication Channels for Disseminating Agricultural Information: The case of North Gondar Zone.
}

\author{
Birhanu Melesse $^{1}$, Yenesew Sewnet ${ }^{2}$, Beyene Derso $^{3}$, and Tigst Petros ${ }^{4}$ \\ ${ }^{1}$ Lecturers in the Department of Rural Development and Agricultural Extension, College of Agriculture and \\ Rural Transformation, University of Gondar, Ethiopia). \\ ${ }^{2}$ Lecturers in the Department of Rural Development and Agricultural Extension, College of Agriculture and \\ Environmental Sciences, Bahir Dar University, Ethiopia). \\ ${ }^{3}$ Lecturers in the Department of Rural Development and Agricultural Extension, College of Agriculture and \\ Rural Transformation, University of Gondar, Ethiopia). \\ ${ }^{4}$ Lecturers in the Department of Rural Development and Agricultural Extension, College of Agriculture and \\ Rural Transformation, University of Gondar, Ethiopia).
}

\begin{abstract}
In Ethiopia, information reaches to farmers mainly through indigenous and exogenous communication channels which include social gatherings, training, meetings, and conferences followed by learning through direct observation. Indigenous communication channels provides an effective means for rural communities to access various types of information related to their farming and day-to-day life. However, the practices and prospects of indigenous communication channels need policy-oriented research to analyze and facilitate meaningful interventions in the areas of agricultural information dissemination. This study was initiated with the objective of identifying existing indigenous Communication Channels used by farm households, assess farmers perception of indigenous Communication Channels utilization to exchange agricultural innovation, analyze the challenges related to exchanging and disseminating of agricultural information with respect to indigenous knowledge and assess indigenous agricultural knowledge preservation practices in the North Gondar Zone. Data were collected from 120 sample household heads, 30 focus group discussants and key informants and both primary and secondary data were used for the study. Household survey, focus group discussion and key informant interview were used to triangulate and strengthen the data collected sample household heads. For the purpose of data analysis, descriptive statistics (frequency \& percentage), and inferential statistics (chi-square test T-test) were used. The results of the study showed that $70 \%$ of the respondents highly preferred indigenous communication channels than exogenous communication channels. The most regularly preferred and utilized channel was Church $(47.5 \%)$, followed by public meeting organized by the community $(22.5 \%)$ where as village meeting organized by the community $(11.7 \%)$ and neighbors $(6.7 \%)$ occupied the third and fourth position in the ranking. It was also indicated that the utilization of indigenous communication channels determined by age and educational status of respondents. In this regard elder and illiterate household heads preferred and utilized indigenous communication channels than exogenous communication channels. Based on the findings, the researchers recommended that indigenous communication channels utilization should be incorporated in the plan of Agricultural Extension Agents, indigenous communication channels should be form as part of agricultural information dissemination package to encourage and facilitate exchanging of information by rural people, Policies, strategies and good practices with respect to indigenous communication channels have to be developed with active participation of primary stakeholders to utilize it effectively.
\end{abstract}

Key word: Agricultural information, Challenges, Exogenous Communication Channels, Indigenous Communication Channels

\section{Introduction}

1.1. Background and Justification of the Study 
Agriculture is the main economic sector in Ethiopia in which the majority of the rural population depends on it .The sector continuous to be the most dominant aspect which accounts for $46 \%$ of GDP, $73 \%$ of employment, and nearly $80 \%$ of foreign export earnings. Furthermore, the majority of the agriculture sector is made up of smallholder farmers whose land size less than 2 hectares. However, the sector faces major challenges in enhancing production in a situation of lacking knowledge necessary for production (ATA, 2014). It is increasingly characterized by new policies, actors, and relationships that influence how smallholders access and use information and knowledge.

Agricultural information is capable of boosting farmers' productivity if the agricultural information dissemination is effectively communicated with the farmers. In Ethiopia, information reaches to farmers mainly through indigenous and exogenous communication channels which include social gatherings, training, meetings, and conferences and followed by learning through direct observation. Hence, the search for appropriate communication channel for agricultural information dissemination has been receiving the attention of the researchers.

Generating new agricultural knowledge and information and making it available for use by smallholder farmers is important in promoting sustainable livelihoods and reducing rural poverty."'(UNDP, 2012). In implementing any agricultural initiatives, an effective and communication channels for disseminating knowledge and information should be considered. "In the context of Ethiopia, indigenous communication channels have a vital role in disseminating agricultural information in rural areas.

Having the right message, the right audience, and the right products may not achieve the intended results unless they are delivered through appropriate channels. Selection and planning of communication channels enhanced its effectiveness by enabling farmers to have access to information. In addition, diversify the extension message communication channels helps to effectively reach farmers in diverse social classes' gender, wealth, age and agro-ecologies. Understanding reasons behind such diversity and farmers current level of access and utilization of agricultural information has a paramount importance. In this study, our focus is on indigenous communication channels. This is because it is a means by which the farmers are familiar and are controlled locally and highly credible. Local audiences are often skeptical of the externally controlled mass media. Most exogenous communication channels are largely confined to urban areas. Even the most widespread exogenous channels, extension personnel and radio which have strategic importance in reaching the majority of the smallholders are not adequately reaching people residing in rural areas (UNDP, 2012). Indigenous channels, by contrast, are needed to convey messages to people out of the reach of exogenous channels.

In Ethiopia, Rural people have well established communication systems through which they traditionally generate, store, share, communicate and utilize information. Indigenous communication channels and networks provide an effective means for rural communities to access various types of information related to their farming and day-to-day life. It lies in the fact that people are familiar with them and can understand, trust, accept and handle them better than externally introduced ones. Indigenous communication channels are heterogeneous, flexible in time, location specific, suited to local socio-cultural conditions, are already in place and so involve less cost, and are accessible to the majority of a community. Indigenous channels can trigger development as informal interactions play a crucial role in influencing people to innovate or change. Interpersonal, peer, and group communication channels are important factors in farmers' decision-making related to agricultural and related activitie (Maulana and Mallya, 2010).

It is also noticed by the researchers that indigenous communication channels play an important role in agricultural information dissemination, complementing and enhancing the effectiveness of exogenous channels. However, the practices and prospects of indigenous communication channels are not well studied in the study area as far as the knowledge of researchers and previous research findings concerned. Hence, policy-oriented research is needed to analyze indigenous communication channels utilization to facilitate meaningful interventions in the areas of agricultural information dissemination in the study area.

\subsection{Objectives of the Study}

The Objectives of the Study were:

- Determine communication channel preference of farm households 
- Identify existing indigenous Communication Channels used by farm households

- Assess farmers perception on indigenous Communication Channels utilization to exchange agricultural information

- Analyze the challenges related to exchanging and disseminating of agricultural information with respect to indigenous knowledge

- Assess indigenous agricultural knowledge preservation practices in the study area

\section{Research Methods}

Location: The former North Gondar Zone is one of the eleventh zones of the region, which has 23 districts and 2,929,628 of total population (ANRS, 2006). It is located in the North-western part of the country between $11^{0} 56^{\prime}$ North latitude and $35^{\circ} 11^{\prime}$ 'East Longitudes, and $738 \mathrm{~km}$ from Addis Ababa. The boundaries of the North Gondar Zone adjoin Tigray region to the North, Ageawe zone and West Gojam zone to the South, Waghimra zone and South Gondar zone to the East and Sudan to the West. The total area of the administrative zone is $50,970 \mathrm{~km}^{2}$. The study was conducted based by taking three sample districts from North Gondar Zone.

\subsection{Research Approach}

The researchers employed mixed (qualitative and quantitative) research approaches. The qualitative data were obtained through focus group discussion (FGD), Key informant Interview (KII) and observation. Quantitative data were obtained from household survey.

\subsection{Sampling Procedures and Techniques}

Multi-stage purposive and simple random sampling techniques were employed to select sample districts, sample kebeles and household heads. North Gondar zone was pre-determined as a study area due to the researchers' prior information about the problem. In the first stage, three districts namely; Gonder Zuria, Dabat and West Belesa districts were selected randomly to have representative districts from North Gondar Zone. Second stage, six kebeles two from each districts were selected by using simple random sampling technique. In the third stage, a total of 120 sample respondents were drown from the updated list of sampling frame found in all sample kebeles through proportion to their household size technique. In addition to individual respondents, data were collected from 30 focus group discussants and 6 key informants. Focus group discussions were arranged in each district to triangulate the data obtained through household survey. Moreover, data also collected from six key informants.

\subsection{Sources and Methods of Data Collection}

The data were collected from both primary and secondary sources. The Primary data were collected through household interviews. The interview schedule pre tested among the 10 non- sampled randomly selected rural households. Then the necessary modifications were done based on the pre tested interview schedule. In addition, the primary data were collected by using key informants interview, focus group discussions triangulate and strengthen the data collected sample household heads. Secondary data were also collected from government annual reports, official statistical abstracts, and research results undertaken in the area.

\subsection{Methods of Data Analysis}

To analyze the collected data, descriptive statistics and inference tests were used. Descriptive statistics like percentage, mean, and standard deviation were used to categorize and analyze personal and socio- economic characteristics of the respondents. In addition, Chi-square test was employed to check the associations and relationships between categorical variables. On the other hand, the qualitative data were analyzed through narration and description. Management and analysis of the data were undertaken by using Statistical Packages for Social Sciences (SPSS version 20.0) software.

\section{Definition of terms}

Indigenous Communication includes the transmission of entertainment, news, persuasion, announcements, and social exchanges of every type - it is an important aspect of culture and the means by which a culture is preserved, handed down, and adapted. 
Exogenous communication transmission of entertainment, news, persuasion, announcements through mass media, schools, agricultural extension, telephone.

\section{Result and Discussion}

\subsection{Demographic, Socio-economic characteristics and Communication channel preference of} respondents

The sex distribution of the respondents in table 1 shows that about 85.8 percent of the respondents were male while the remaining (14.2\%) were female. The result of the study revealed that the majority of the rural respondents were male while small proportions of them were female respondents. Tablelgives the details and $86.90 \%$ of male respondents preferred indigenous communication channels. Similarly, $73 \%$ of female respondents also preferred it for disseminating agricultural information.

Regarding to education status, $56 \%$ of illiterate respondents preferred indigenous communication channels while $75 \%$ of literate respondents preferred exogenous communication channels to disseminate agricultural information. There is an association in the preference of communication channels among illiterate and literate respondents at $\mathrm{p}=9.7$. Illiterate respondents were more likely to prefer and utilize indigenous communication channels as compared with literate respondents. This is most probably due to indigenous communication channels simple to use and accessible by everyone.

The communication channels preference of respondents and their age category are shown in the figure 1 . It is shown that the majority of the respondents were in the age group of $60^{+}$and they preferred indigenous communication channels (33.3\%), while the proportion in the age groups 31-45 and 46-60 accounts for about $27.8 \%$ and $30.6 \%$ respectively and they preferred exogenous communication channels. Looking at the age distribution of respondents in the age group $\left(60^{+)}\right.$are elder respondents and they are in a position to prefer the indigenous channels because of its accessibility and even they understand it easily. On the other hand, most youth respondents were not receptive to indigenous channels due to modernization and a formal education system.

The respondents were asked to indicate the most preferred channel available and accessible to them. The Indigenous communication channels are highly preferred by respondents (70\%) than exogenous communication channels. In the study area, indigenous communication channels seem to relatively dominate which could be the result of strong social links that exist. In addition, rural people living in isolated villages without access to modern means of communication have relied on the indigenous forms of communication as a means of sharing knowledge and information and providing entertainment. Moreover, indigenous communication channels provide many opportunities for informal interaction occurs in many other settings: talk at home, in the fields and at the market, and wherever else people meet and talk. In contrast, exogenous channels have limited coverage, are more rigid, and local people are often disbelieving about externally controlled channels and information. Even radio, TV and mobile phones, the most widespread forms of exogenous channels, fail to reach many rural people around rural areas of Ethiopia.

\section{Table 1: Preference of communication channel by respondents}

\begin{tabular}{|l|l|l|c|c|c|}
\hline variables & category & & \multicolumn{2}{|c|}{$\begin{array}{c}\text { Preference of communication } \\
\text { channel by Respondents }\end{array}$} & Total $\mathrm{X}^{2}$ - Value \\
\cline { 3 - 6 } & & $\begin{array}{c}\text { Exogenous } \\
\text { communication } \\
\text { channels }\end{array}$ & $\begin{array}{c}\text { Indigenous } \\
\text { communication } \\
\text { channels }\end{array}$ & \\
\hline \multirow{3}{*}{$\begin{array}{l}\text { sex of } \\
\text { respondents }\end{array}$} & Female & $\mathrm{N}$ & 6 & 11 & 17 \\
\cline { 3 - 6 } & Male & $\mathrm{N}$ & $16.70 \%$ & $13.10 \%$ & $14.20 \%$ \\
\cline { 3 - 6 } & $\%$ & $83.30 \%$ & 73 & 103 \\
\hline Total & $\mathrm{N}$ & 36 & $86.90 \%$ & $85.80 \%$ \\
\hline
\end{tabular}




\begin{tabular}{|c|c|c|c|c|c|c|}
\hline \multirow{5}{*}{\begin{tabular}{|l|} 
\\
education \\
status of \\
respondents
\end{tabular}} & & $\%$ & $30 \%$ & $70.00 \%$ & $100.00 \%$ & \\
\hline & \multirow[t]{2}{*}{ Illiterate } & $\mathrm{N}$ & 9 & 47 & 56 & \\
\hline & & $\%$ & $25.0 \%$ & $56.0 \%$ & $46.7 \%$ & $9.7 * *$ \\
\hline & \multirow[t]{2}{*}{ Literate } & $\mathrm{N}$ & 27 & 37 & 64 & \\
\hline & & $\%$ & $75.0 \%$ & $44.0 \%$ & $53.3 \%$ & \\
\hline \multirow{2}{*}{\multicolumn{2}{|c|}{ Total }} & $\mathrm{N}$ & 36 & 84 & 120 & \\
\hline & & $\%$ & $30.0 \%$ & $70.0 \%$ & $100.0 \%$ & \\
\hline \multirow{8}{*}{$\begin{array}{l}\text { age of } \\
\text { respondents }\end{array}$} & \multirow[t]{2}{*}{$15-30$} & $\mathrm{~N}$ & 4 & 12 & 16 & \\
\hline & & $\%$ & $11.1 \%$ & $14.3 \%$ & $13.3 \%$ & \\
\hline & \multirow[t]{2}{*}{$31-45$} & $\mathrm{~N}$ & 10 & 22 & 32 & \\
\hline & & $\%$ & $27.8 \%$ & $26.2 \%$ & $26.7 \%$ & \\
\hline & \multirow[t]{2}{*}{$46-60$} & $\mathrm{~N}$ & 11 & 22 & 33 & \\
\hline & & $\%$ & $30.6 \%$ & $26.2 \%$ & $27.5 \%$ & \\
\hline & \multirow[t]{2}{*}{$>=60$} & $\mathrm{~N}$ & 11 & 28 & 39 & \\
\hline & & $\%$ & $30.6 \%$ & $33.3 \%$ & $32.5 \%$ & \\
\hline \multirow{2}{*}{\multicolumn{2}{|c|}{ Total }} & $\mathrm{N}$ & 36 & 84 & 120 & \\
\hline & & $\%$ & $100.0 \%$ & $100.0 \%$ & $100.0 \%$ & \\
\hline
\end{tabular}

Source: Household Survey Data, 2017

Respondents were asked about the accessibility and ownership of different exogenous communication channels. And $95 \%$ of them do not have access to TV, $90.8 \%$ and $76.7 \%$ had no Radio and mobile phone to exchange agricultural information at the time of data collection. This indicates that the accessibility and availability of exogenous communication channels is limited in rural areas and it makes the rural households preferred indigenous communication channels. Thus, rural people have to effectively employing indigenous communication channels to secure their different needs harmoniously ((Mushengyezi, 2004) cited in Hagos, 2010).

Table 2: Respondents access to mobile phone, Radio and TV to obtain agric information

\begin{tabular}{|l|l|r|r|}
\hline \multicolumn{2}{|l}{$\begin{array}{l}\text { Variables } \\
\text { Category }\end{array}$} & Frequency & \multicolumn{2}{|c|}{ Percent } \\
\hline \multirow{3}{*}{ Access to listening to radio } & Yes & 11 & 9.2 \\
\cline { 2 - 4 } & No & 109 & 90.8 \\
\cline { 2 - 4 } & Total & 120 & 100.0 \\
\hline \multirow{3}{*}{ Cell Phone } & Yes & 28 & 23.3 \\
\cline { 2 - 4 } & No & 92 & 76.7 \\
\cline { 2 - 5 } & Total & 120 & 100.0 \\
\hline Access to watching Television & Yes & 6 & 5.0 \\
\cline { 2 - 5 } & No & 114 & 95.0 \\
\cline { 2 - 5 } & Total & 120 & 100.0 \\
\hline
\end{tabular}

Source: Household Survey Data, 2017

Respondents were asked about the reasons for preferring the indigenous communication channels. Out of the total respondents, $98.8 \%, 96.4 \%$ of them preferred indigenous communication channels because of its availability and the satisfaction it gives to them. The results of the focus group discussion and key informant interviews also confirmed that they preferred it since they trust their relatives and neighbors' information than the modern communication channels, due to its proximity in giving and receiving information and the facilitation is carried out by themselves. 
Table 3: Reasons for preferring the communication channels

\begin{tabular}{|c|c|c|c|c|c|c|c|c|c|}
\hline \multirow{4}{*}{$\begin{array}{l}\text { S.n } \\
0\end{array}$} & \multirow{4}{*}{$\begin{array}{l}\text { Reasons for preferring the } \\
\text { communication channel }\end{array}$} & \multicolumn{8}{|c|}{ Response category } \\
\hline & & \multicolumn{4}{|c|}{$\begin{array}{l}\text { Exogenous } \\
\text { communication channel }\end{array}$} & \multicolumn{4}{|c|}{$\begin{array}{c}\text { Indigenous } \\
\text { communication channel }\end{array}$} \\
\hline & & \multicolumn{2}{|c|}{ Yes } & \multicolumn{2}{|c|}{ No } & \multicolumn{2}{|c|}{ Yes } & \multicolumn{2}{|c|}{ No } \\
\hline & & $\mathrm{N}$ & $\%$ & $\mathrm{~N}$ & $\%$ & $\mathrm{~N}$ & $\%$ & $\mathrm{~N}$ & $\%$ \\
\hline 1 & Easily available & 29 & 80.6 & 7 & $\begin{array}{l}19 . \\
4\end{array}$ & 83 & $\begin{array}{r}98 . \\
8\end{array}$ & 1 & 1.2 \\
\hline 2 & Less expensive & 6 & 16.7 & 30 & $\begin{array}{l}83 . \\
3\end{array}$ & 75 & $\begin{array}{r}89 . \\
3\end{array}$ & 9 & 10.7 \\
\hline 3 & Community ownership & 33 & 91.7 & 3 & $\begin{array}{c}8 . \\
3\end{array}$ & 73 & $\begin{array}{r}86 . \\
9\end{array}$ & 11 & 13.1 \\
\hline 4 & $\begin{array}{l}\text { Credible source among } \\
\text { community }\end{array}$ & 33 & 91.7 & 3 & $\begin{array}{r}8 . \\
3\end{array}$ & 75 & $\begin{array}{r}89 . \\
3\end{array}$ & 9 & 10.7 \\
\hline 5 & Satisfy my need & 33 & 91.7 & 3 & $\begin{array}{c}8 . \\
3\end{array}$ & 81 & $\begin{array}{r}96 . \\
4\end{array}$ & 3 & 3.6 \\
\hline 6 & Timelines of information & 31 & 86.1 & 5 & $\begin{array}{l}13 . \\
9\end{array}$ & 74 & $\begin{array}{r}88 . \\
1\end{array}$ & 10 & 11.9 \\
\hline & & & & & & & & & \\
\hline
\end{tabular}

\subsection{Existing Indigenous Communication Channels used by farm Households}

In the rural area of Ethiopia, different indigenous Communication Channels have been using by farm households for disseminating agricultural information. The existing indigenous communication channels most commonly used by respondents were obtained from the survey result and it is illustrated in Table 3 . Among the indigenous communication channels used for disseminating agricultural information by respondents, the most regularly utilized channels were Church $(47.5 \%)$, followed by public meeting organized by the community $(22.5 \%)$ where as village meeting organized by the community $(11.7 \%)$ and neighbors $(6.7 \%)$ occupied the third and fourth position. On the other hand, Market centers (2.5\%), Mahiber (4.2\%), Senbete $(2.5 \%)$ and Relatives $(2.5 \%)$ were identified as the least utilized channels by the respondents. The result of the study revealed that church has higher relative usage by farmers than other indigenous communication channels. This may due to the respondents' disseminate to and receive information during religious festivals and funeral from their relatives and the community at large. The indigenous communication channels identified during the FGD were religious ceremonies, coffee ceremony, marriage ceremonies and Debiat. Specially, female farmers in West Belessa have been exchanging agricultural information by arranging coffee ceremony around their village. It is common means of sharing agricultural information and it is known as 'Yesetoch Weg' or 'Tertim'. In addition, in the study area, female farmers have been exchanging information while they are fetching water. This indicates that the needs of communication channels differ among men and women farmers. For example, "Dagu" is a communication channel found in Afar region that is a suitable communication approach on which elder Afar men are the smart information exploiters, while females and children under fifteen do not have the opportunity to use" Dagu" like the others (Moges Endris, 2010). Hence, considering the communication channel needs of female farmers can help to promote their participation in exchanging agricultural information. 
Figure 1: Utilization of indigenous Communication Channels by Respondents

which indigenous communication channel you have been using more for exchanging agricultural information?

- Percent

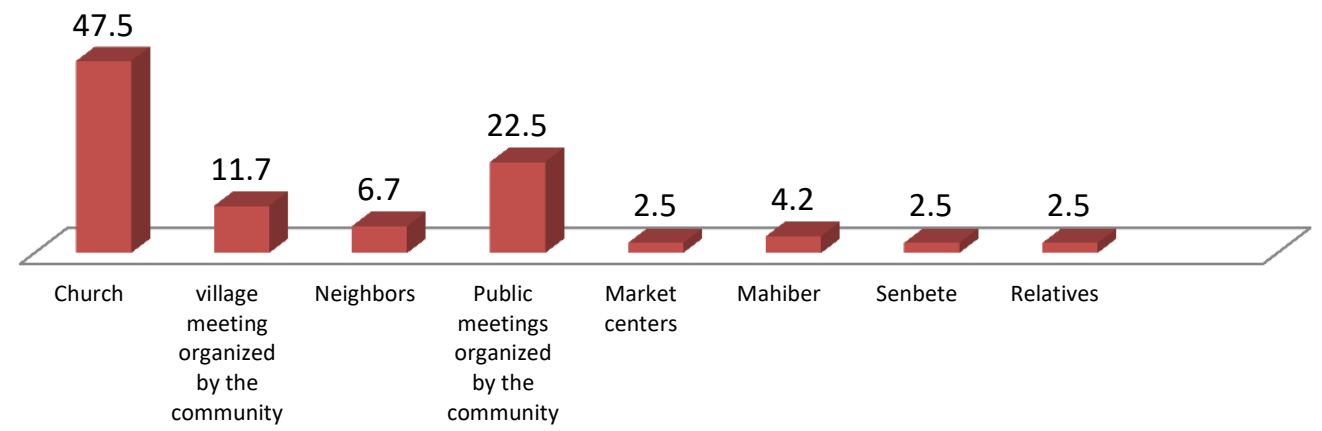

Source: Household Survey Data, 2017

\subsection{Farmers' Perception on Indigenous Communication Channels Utilization to Exchange Agricultural Information}

Farmers' perceptions of indigenous Communication Channels were measured in five statement items and the result indicated in table 4 . In this case, it was hypothesized that farmers have diversified level of agreement on the characteristics of indigenous Communication Channels. Respondents were asked to express their level of agreement whether indigenous communication channels are cheaper and $58.3 \%$ of the respondents strongly agreed while $28.3 \%$ agreed that indigenous communication channels are cheaper as compared to exogenous channels. Therefore, Farmers' perception of the cost of indigenous Communication Channels is less than exogenous channels. Meanwhile $48.3 \%$ and $37.5 \%$ of the respondents disagreed in its advantage and provision of timely feedback under item 4 and 5. Item 2 indicates that $44.2 \%$ and $38.3 \%$ of the respondents strongly agreed and agreed that indigenous communication channels are effective in disseminating agricultural information. Similarly, item 3 show that $51.7 \%$ and $34.2 \%$ of the respondents indicate that indigenous communication channels are simple to understand. Moreover, $33.3 \%$ and $32.5 \%$ of the respondents in item 6 indicates that indigenous communication channels motivate the respondents to participate in different agricultural activities.

Table 4: Farmers' perception on indigenous Communication Channels utilization

\begin{tabular}{|c|c|c|c|c|c|c|c|c|c|c|c|}
\hline \multirow{3}{*}{$\begin{array}{l}\text { S. } \\
\text { n } \\
\text { o }\end{array}$} & \multirow{3}{*}{ Category } & \multicolumn{10}{|c|}{ Decision level } \\
\hline & & \multicolumn{2}{|c|}{$\begin{array}{l}\text { Strongly } \\
\text { agree }\end{array}$} & \multicolumn{2}{|c|}{ Agree } & \multicolumn{2}{|c|}{$\begin{array}{l}\text { Undecid } \\
\text { ed }\end{array}$} & \multicolumn{2}{|c|}{ Disagree } & \multicolumn{2}{|c|}{$\begin{array}{l}\text { Strongly } \\
\text { disagree }\end{array}$} \\
\hline & & No & $\%$ & No & $\%$ & No & $\%$ & No & $\%$ & No & $\%$ \\
\hline 1 & $\begin{array}{l}\text { Indigenous communication } \\
\text { channels are cheaper than } \\
\text { other communication } \\
\text { channels }\end{array}$ & $\begin{array}{l}7 \\
0\end{array}$ & $\begin{array}{r}58 . \\
3\end{array}$ & 34 & 28.3 & 5 & 4.2 & 9 & $\begin{array}{r}7 . \\
5\end{array}$ & 2 & 1.7 \\
\hline 2 & $\begin{array}{l}\text { Indigenous communication } \\
\text { channels are effective in } \\
\text { disseminating agricultural } \\
\text { Information }\end{array}$ & 53 & 44.2 & 46 & 38.3 & 4 & 3.3 & 15 & $\begin{array}{l}12 . \\
5\end{array}$ & 2 & 1.7 \\
\hline 3 & $\begin{array}{l}\text { Information dissemination } \\
\text { through Indigenous } \\
\text { Communication channels is } \\
\text { Simple to understand }\end{array}$ & 62 & 51.7 & 41 & 34.2 & 6 & 5.0 & 9 & 7.5 & 2 & 1.7 \\
\hline 4 & $\begin{array}{l}\text { Indigenous Communication } \\
\text { channels provides timely }\end{array}$ & $\begin{array}{l}1 \\
5\end{array}$ & $\begin{array}{r}12 . \\
5\end{array}$ & 31 & 25.8 & 25 & $\begin{array}{l}20 . \\
8\end{array}$ & 45 & $\begin{array}{l}37 . \\
5\end{array}$ & 4 & $\begin{array}{r}3 . \\
3\end{array}$ \\
\hline
\end{tabular}




\begin{tabular}{|l|l|r|r|r|r|r|r|r|r|r|r|}
\hline & feedback & & & & & & & & & & \\
\hline 5 & $\begin{array}{l}\text { Indigenous Communication } \\
\text { channels has equal } \\
\text { advantage as exogenous } \\
\text { channels }\end{array}$ & 1 & 9.2 & 28 & 23.3 & 1 & $\begin{array}{l}10 . \\
8\end{array}$ & $\begin{array}{l}5 \\
8\end{array}$ & $\begin{array}{l}48 . \\
3\end{array}$ & 10 & 8. \\
& & & & & & & & & \\
\hline 6 & $\begin{array}{l}\text { Indigenous communication } \\
\text { channels offers } \\
\text { opportunities for } \\
\text { participation by local people }\end{array}$ & 4 & 33. & 39 & 32.5 & 1 & 13. & 1 & 13. & 9 & 7. \\
\hline
\end{tabular}

Source: Household Survey Data, 2017

\subsection{Challenges related to exchanging and Disseminating Agricultural information with respect to Indigenous Communication Channels}

The available data from the household survey shows that the recognition given to indigenous communication channels and the attention given to indigenous communication channels (64.6\%), (94.2\%) were the main challenges in exchanging and disseminating agricultural information with respect to indigenous knowledge in the study area (see Figure 2). During the key informant interview conducted in Dabat district, the indigenous communication channels have not planed, prioritized, and adequately preserved to disseminate agricultural information. It was also indicated that the concerned stakeholders have not discharging their responsibilities to use efficiently indigenous communication channels for disseminating agricultural information. Other common challenges in using indigenous communication channels were poor knowledge sharing culture (80\%), lack of awareness (80.8\%), and low level of use of folk media $(67.5 \%)$. Other factors that inhibited farmers in using indigenous communication channels were lack of documentation and low level of communication among stakeholders. In addition, the following challenges were identified by the participants of FGD and key informant interview:

- Dissemination of unreliable information among the community,

- Traditional healers did not transfer their knowledge to others except their children

- Inequitable distribution of information in all areas at a time

- Lack of plan how farmers can get information using indigenous communication channels

Figure 4: Challenges related to indigenous communication channels

Challenges Related to Indigenous Communication Channels in \%

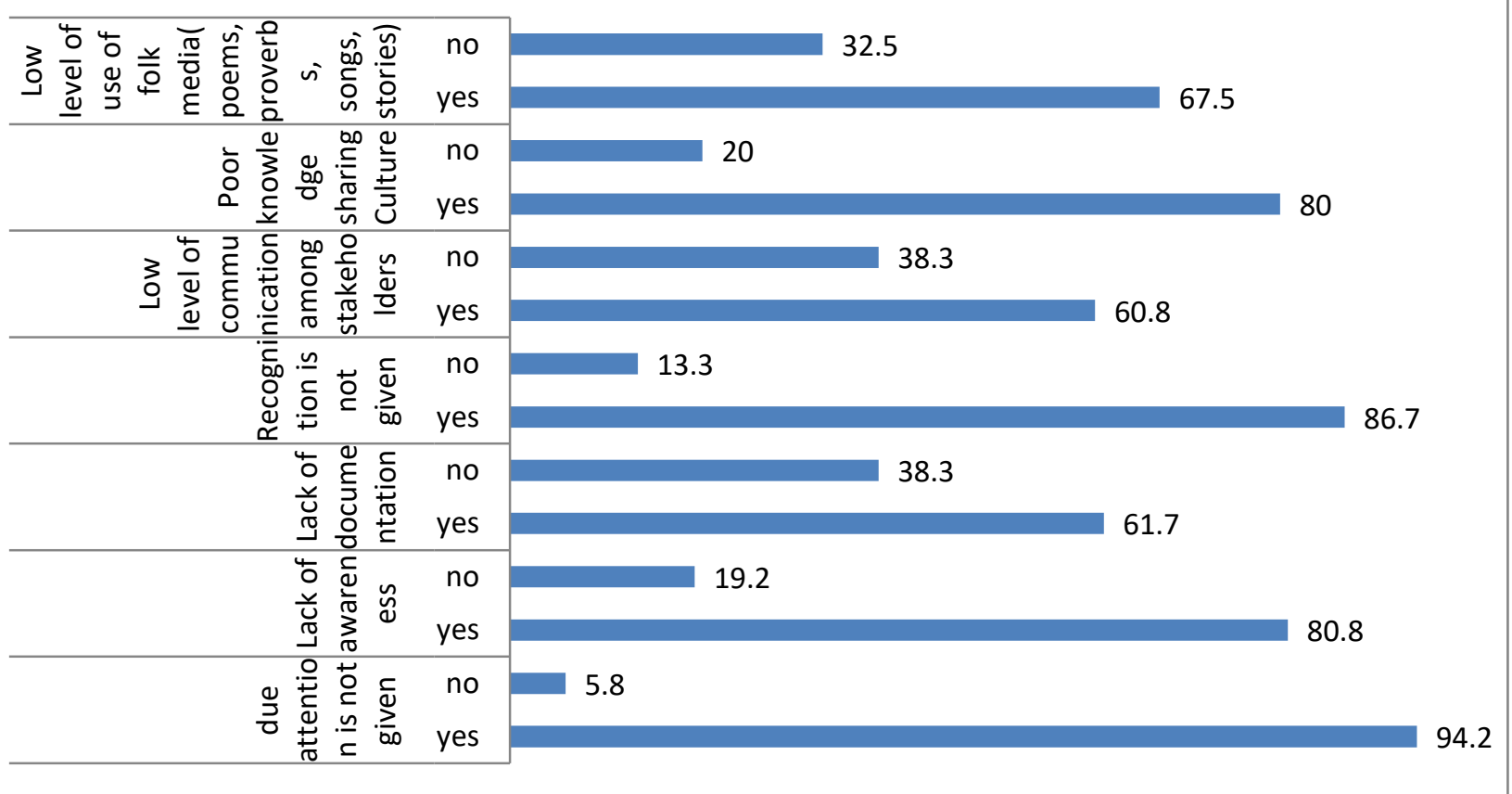

Source: Household Survey Data, 2017 


\subsection{Indigenous agricultural knowledge preservation practices by using Indigenous communication channels}

In rural communities, rural households are endowed with indigenous knowledge of traditional land use and management, climate change adaptation, breeding of animal species. Preservation of such knowledge is an essential part of information dissemination. However, the indigenous knowledge preservation is not adequately done to capture for a valuable database of knowledge that provides humankind with insights on how numerous communities have interacted with their changing environments. In this regard respondents were asked the existence of indigenous knowledge preservation practice in the community. And 54.2\% of the respondents confirmed that the existence of the practice while $45.8 \%$ did not know whether it exists or not. Table 4 shows the frequency distribution of the preservation practices how they have been transferring their knowledge.

Figure 5: Indigenous knowledge preservation practices

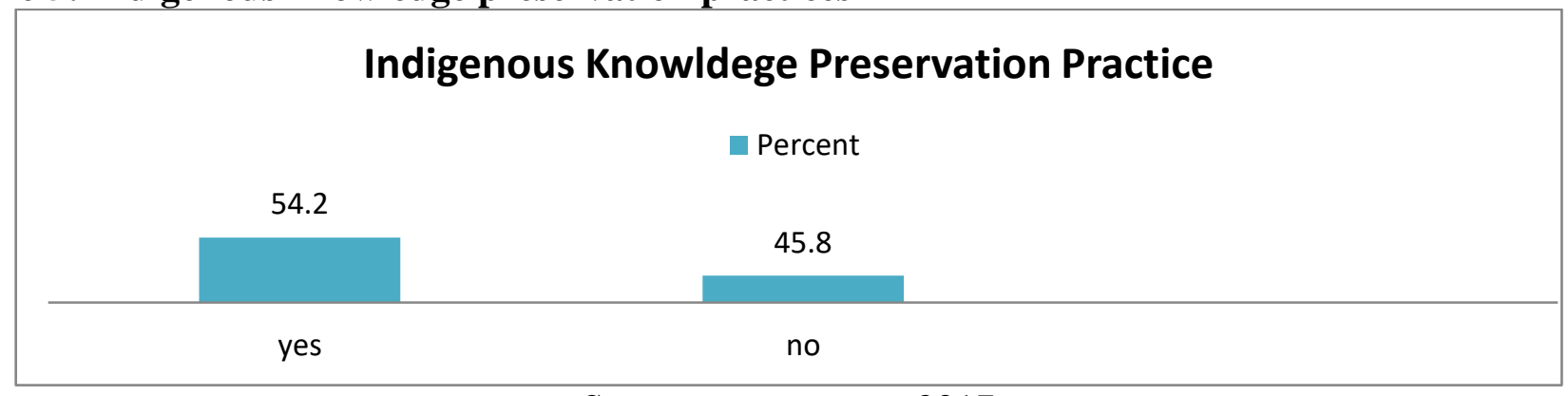

Source: own survey, 2017

The respondents have used different means to transfer their indigenous knowledge to others. $38 \%$ Telling to their child, using electronics $1.7 \%$, written document $8.3 \%$, proverbs or song $5 \%$. It gives a clue to use and preserve

Figure 6: Means of preservation of agricultural indigenousness knowledge

\begin{tabular}{l} 
Means of preservig /transfering \\
\multicolumn{1}{c}{$\begin{array}{c}\text { Percent } \\
1.7\end{array}$} \\
$\begin{array}{c}\text { Using electronics } \\
\text { (Tape, } C D \text {, mobile) }\end{array}$
\end{tabular}

Source: Household Survey Data, 2017

\section{Reasons for lack of preserving the Indigenous knowledge}

Indigenous knowledge is "an important asset with regard to the social capital of local people and constitutes the main resource for their livelihoods" (Lwoga, et al., 2011), it is imperative to preserve and manage indigenous knowledge in a way that best suit their needs. However, preservation of indigenous knowledge is greatly affected by the very nature of the knowledge that is individual based thus making it difficult to disseminated to other people. The knowledge is communicated to the child by its parents, or it could be ancestors communicating to one through dreams, incomprehensible language to many except the recipient only. For instance, a study conducted in South-western Ethiopia indicated that farmers have a wide range of indigenous knowledge relating to maize production, crop protection and utilization, but much of this was being neglected and eroded mainly as a result of the promotion of modern technology packages such as hybrid seeds and associated inputs and practices (Negussie et al., 2005). The reasons could include the centralized and top-down approach, lack of active community participation, and overreliance on external information and technology delivery strategies and channels. As the FGD and KII result indicates that farmers have started good practice documentation from land preparation up to harvesting (Personal communication, 2017). This kind of intervention will make them to preserve their Indigenous knowledge. 


\section{Reasons for lack of preserviation of indigenous knowldege in \%}

24.2

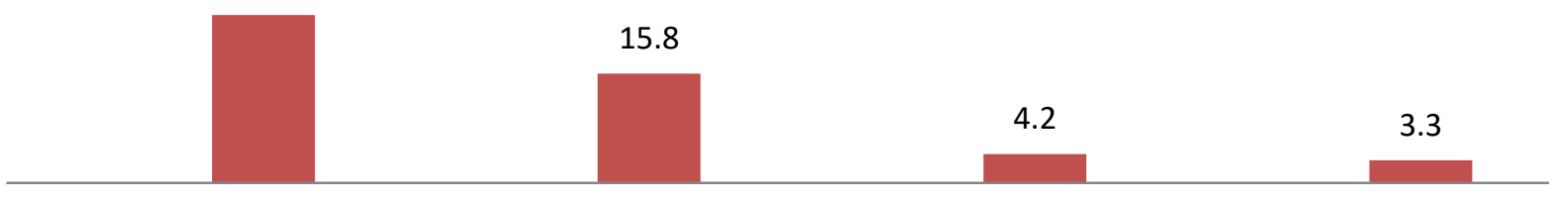

\begin{tabular}{|c|c|c|c|}
\hline $\begin{array}{l}\text { Lack of skill how to } \\
\text { eserving the indigenous } \\
\text { agricultural practices }\end{array}$ & $\begin{array}{c}\text { Absence of indigenous } \\
\text { knowledge documentation } \\
\text { centers }\end{array}$ & $\begin{array}{l}\text { Lack how to use different } \\
\text { information } \\
\text { communication } \\
\text { technologies }\end{array}$ & $\begin{array}{l}\text { Due attention is not given } \\
\text { by the responsible bodies }\end{array}$ \\
\hline
\end{tabular}

Source: Household Survey Data, 2017

\section{Conclusion and Recommendations}

\subsection{Conclusion}

Based on the major findings of the study, the following conclusions were drawn. The Indigenous communication channels are highly preferred by respondents than exogenous communication channels. They preferred indigenous communication channels because of its availability and the satisfaction it gives to them. The most regularly utilized indigenous communication channels by respondents were Church followed by public meeting, village meeting and neighbors. The result of the study shows that church has higher relative usage by farmers than other indigenous communication channels. It was also indicated that the utilization of indigenous communication channels determined by age and educational status of respondents. In this regard elder and illiterate household heads preferred and utilized indigenous communication channels than exogenous communication channels. The finding of the study indicates that respondents agreed that indigenous communication channels are cheaper, effective in disseminating agricultural information, simple to understand, motivate them to participate in different agricultural activities. The challenges identified by the respondents in using indigenous communication channels were; the attention and recognition given, lack of plan, priority, and dissemination of unreliable information among the community to disseminate agricultural information.

\section{Recommendation}

- It was indicated that majority of the respondents preferred indigenous communication channels. This is therefore critical to identify channels used by the farmers to disseminating agricultural information.

- Utilization of indigenous communication channels determined by age and educational status of respondents. In this regard, Agricultural Extension Agents should segment the farmers based on their age and educational status to effectively disseminate agricultural information.

- The result of the study indicates that indigenous communication channels were not properly planned in disseminating agricultural information. Hence, Agricultural Extension Agents/Extension Communication experts should incorporate the indigenous communication channels in their plan of action.

- The results of this study also indicates that the indigenous communication channels should be further strengthened and used more effectively by establishing center of documentation in the districts Agriculture Office to preserve it for the future generation.

- Indigenous communication channels should be form as part of agricultural information dissemination package at district agricultural extension to encourage and facilitate exchanging of information by rural people

- Policies, strategies and good practices with respect to indigenous communication channels have to be developed with active participation of stakeholders to use it effectively. 


\section{References}

[1] ATA (Agricultural Transformation Agency, 2014). Annual Report: Transforming Agriculture in Ethiopia. Addis Ababa, Ethiopia.

[2] Hagos Nigussie. (2010). The Use of Indigenous Communication in HIV Prevention in Erob Woreda, North Eastern Tigray. Graduate school of journalism and communication: unpublished Masters Thesis. Addis Ababa University

[3] Lwoga, Edda Tandi. (2011). Knowledge management approaches in managing agricultural indigenous and exogenous knowledge in Tanzania. Journal of Documentation, 67(3), 407-430.

[4] Moges Endris.(2010). Dagu As a cultural regulator among the afar people: the communication aspect .graduate school of journalism communication. Unpublished Master's Thesis: Addis Ababa University.

[5] Negussie, E., Monica, G. and Phelan, J. 2005. Implications of an extension package approach for farmers' indigenous knowledge. The maize extension package in South-Western Ethiopia. Journal of International Agricultural Exten

[6] Sosena O. (2016). The role of ICT in Agricultural Knowledge Communication in ATA. Graduate school of journalism and communication: unpublished Master's Thesis.: Addis Ababa University, Ethiopia

[7] UNDP.2012.United Nation Development Program (UNDP-Ethiopia).Promoting ICT based Agricultural knowledge management to increase production and productivity of Smallholder farmers in Ethiopia. 